\title{
Dermatoglyphics as a possible morphological biomarker in myopia: analysis of finger ridge counts and fluctuating asymmetry
}

\author{
L. Sretić ${ }^{1}$, N. Labus ${ }^{1}$, T. Filipović ${ }^{2}$, M. Filipović ${ }^{3}$ \\ ${ }^{1}$ Department of Biology, Faculty of Sciences and Mathematics, University of Priština-Kosovska Mitrovica, \\ Kosovska Mitrovica, Serbia \\ ${ }^{2}$ Department of Anatomy, Medical Faculty, University of Priština-Kosovska Mitrovica, Kosovska Mitrovica, Serbia \\ ${ }^{3}$ Department of Surgery, Medical Faculty, University of Priština-Kosovska Mitrovica, Kosovska Mitrovica, Serbia
}

[Received: 11 June 2018; Accepted: 11 July 2018]

Background: The aim of this study is to provide the first analysis of finger ridge counts and fluctuating asymmetry in myopia, in order to evaluate dermatoglyphic role as a morphological biomarker.

Materials and methods: Study sample consisted of 102 participants recruited from freshman students' population of the University of Priština-Kosovska Mitrovica. Prints were taken by standard ink and paper method. Differences in mean ridge counts between examined groups were analysed by ANOVA analysis of variance. Fluctuating asymmetry assessment was performed by using correlation method $(p<0.05)$.

Results: Analysis has identified myopic males as the group with the most prominent differences of examined dermatoglyphic parameters. Myopic males, compared to controls, have significantly higher ridge counts for left and right ring and little finger, as well as total ridge count. Also, this group has recorded significant difference in fluctuating asymmetry correlation score for middle finger, and borderline significance for thumb and ring finger.

Conclusions: Overall findings of this study have indicated that dermatoglyphics might serve as a morphological biomarker, especially in myopic males, selecting them as the group with dermatoglyphic differences that might be suggestive of higher developmental instability. Although promising, the present results should be considered as preliminary until future investigations replicate them in a larger sample. (Folia Morphol 2019; 78, 2: 425-430)

Key words: dermatoglyphics, myopia, fluctuating asymmetry, developmental instability

\section{INTRODUCTION}

Dermatoglyphics is a term that originates from two Greek words, $\delta \dot{\varepsilon} \rho \mu \alpha$ - skin and $\gamma \lambda \dot{v} \varphi \dot{\eta}$ - carving, describing a study of a system of cutaneous ridges and furrows flowing in distinctive paths or directions on fingers, palmar and plantar surfaces. Dermal ridges are derived as an evolutionary adaptation that enhances tactile sensation and friction, and are unique characteristic typically found in higher primates or, sporadically, in other mammals [31]. The pattern of ridged skin is established from $6^{\text {th }}$ to $17^{\text {th }}$ week of gestation, when the basal layer of the volar epidermis

Address for correspondence: Dr. L. Sretić, Department of Biology, Faculty of Sciences and Mathematics, University of Priština-Kosovska Mitrovica, Ive Lole Ribara 29, 38220 Kosovska Mitrovica, Serbia, tel: +381638277826, e-mail: Isretic@gmail.com 
becomes folded forming primary ridges. This process is influenced by the volar pads, local temporary eminences of the subcutaneous tissue and the sites of ridge formation. Subsequent environmental insults, that follow full maturation of secondary ridges during $24^{\text {th }}$ week, remain basic dermatoglyphic structure unaffected, making them "a history of development" [3].

Heredity of quantitative dermatoglyphic traits conforms to polygenic system, with individual genes contributing a small additive effect, but the prenatal environment may also exert an important influence [2]. Finger ridge count is one of the most heritable anthropometric features, and has been used as a model trait for the study of human quantitative genetics $[7,29]$. Since that genetic component affect ridge composition indirectly, through ontogenetic factors such as embryonic pad topography, growth stress, neurotrophic or skeletal factors, it is not the pattern of friction ridge skin that is passed down through heredity, but the shape and location of volar pads $[3,21]$. As a result of their polygenic inheritance, which makes them less susceptible and less vulnerable to stochastic processes, such as genetic drift, dermatoglyphics are widely used in population studies [1]. Besides, due to their polygenic determination, genes underlying certain disorder may, by pleiotropy, affect dermatoglyphic parameters [12]. This makes them, along with lifetime permanence and the fact that forces that channel ridge differentiation must be operating prior the $19^{\text {th }}$ week of gestation, a sensitive indicator of intrauterine disturbances associated with chromosomal/gene abnormalities, environmental stress, or a combination of these [28]. Altered dermatoglyphic configuration has been proven in numerous multifactorial or chromosomal disorders $[22,28,35]$.

One of the most common public health issues in the world is myopia [11]. Eye morphogenesis is extremely precise, genetically determined process [15], involving ectodermal and neuroectodermal derivatives [39]. Uncoordinated contribution of ocular components may lead to myopia, a multifactorial eye disorder characterised by blurred vison of distant objects [44]. Strong genetic background of myopia onset has been proven in two recent largescale genome-wide association studies that have identified significant association of several candidate genes, involved in neurotransmission, ion transport, retinoic acid metabolism, extracellular matrix remodelling and eye development, with this type of visual impairment [25].
Bilaterally represented traits demonstrate three types of asymmetry, differentiated by their causes and biological significance: directional asymmetry, antisymmetry and fluctuating asymmetry. The aetiology of directional asymmetry and antisymmetry may be regarded as a part of the developmental plan, and therefore likely to have an adaptive significance [5, 13]. Fluctuating asymmetry signifies small, random departures from perfect symmetry between the left and right side of a bilateral trait, where the right-left variation is normally distributed about a mean of zero [32]. It is considered that fluctuating asymmetry stems from inability of the organism to buffer negative influences of disturbing developmental factors, indirectly reflecting the level of stress experienced during development $[6,42]$. Since that development of bilateral symmetrical traits is under control of identical genes the underlying assumption of fluctuating asymmetry analysis is that nondirectional differences between two sides are of environmental origin, reflecting insults during developmental time $[23,37]$.

The main objective of this study was to investigate effects of myopic visual impairment on finger ridge counts and levels of fluctuating asymmetry, in order to determine possible role of dermatoglyphics as a morphological marker.

\section{MATERIALS AND METHODS}

Study sample consisted of 102 participants recruited from the freshman students' population of the University of Priština-Kosovska Mitrovica. Among them, 51 were diagnosed with common myopia, from -1 to -5 dioptres, and 51 composed healthy control group (both groups included 26 females and 25 males). Individuals were aligned by sex and vision as control males, control females, myopic males and myopic females. Prints were taken by standard ink and paper method described by Cummins and Midlo [8]. Scanned nail-to-nail rolled impressions of inked fingertips (CanoScanLiDE 25) were enlarged by image editing software programme Adobe Photoshop CS3, and scored. Comparisons were made between control and myopic individuals of the same sex.

Quantitative analysis encompassed finger ridge counts (FRC) and total ridge count (TRC). Finger ridge count is defined as number of ridges intersected with the line drawn from the core, centre of a pattern, and triradius, point of three ridge systems confluence at an angle of approximately $120^{\circ}$. Arch pattern has no triradius, so the score for ridge count is zero, loops have one and whorls two, yielding two counts, but 
only higher is used for finger ridge or total ridge count. Total ridge count is a common composite trait calculated by summing ridge counts for all 10 fingers. Fingers of the left and right hand were designated as FRCL1-5 and FRCR1-5. Mean finger ridge counts were analysed in relation to their variability between examined groups using univariate analysis of variance (ANOVA).

Fluctuating asymmetry assessment was performed by using correlation method, since that it is not affected by directional asymmetry [36]. Pearson's product-moment correlation coefficient $(r)$ was applied for the comparison of ridge counts between homologous fingers. $r^{2}$ is a measure of their common variance; $1-r^{2}$ is an estimate of error variance and thus a measure of fluctuating asymmetry [40]. Statistical significance of differences in correlation coefficients between myopic and control males, as well as females, was calculated using Fischer's z-transformation [10]. Analysis of correlation was performed by SPSS7 (Statistica for Windows; StatSoft, Inc., Tulsa, OK, USA), while the Fischer's z transformation was calculated employing a test available on Internet [24]. The level of significance for all reported differences was set at $\mathrm{p}<0.05$.

The protocol and informed consent procedure was approved by Institutional Ethical Committee.

\section{RESULTS}

Means and standard deviations for left and right finger ridge counts in control and myopic males and females are shown in Table 1.

The results of univariate analysis of variance (ANOVA), presented in Table 2, point to significant heterogeneity in ridge counts between myopic and control males for both left and right ring ( $p=0.0198$, $p=0.0009$. respectively) and little finger $(p=0.0026$, $p=0.0005$, respectively), and total ridge count $(p=0.0353)$, as a consequence of elevated values in myopic males. The only significance in ridge counts between myopic and control females was recorded for left little finger $(p=0.027)$, being lower in myopic females.

Data presented in Table 3, displaying fluctuating asymmetry indices $\left(1-r^{2}\right)$, Fisher's z-transformation ( $z$ ) and significance $(p)$, reveal higher levels of fluctuating asymmetry in myopic males and females compared to controls. The only significant variation was found in myopic males for middle finger $(p=0.017)$, but there was also a clear tendency to significance for thumb and ring finger ( $p=0.058, p=0.054$, respectively).

\section{DISCUSSION}

Current paper is, to the best of our knowledge, the first attempt to investigate finger ridge counts and fluctuating asymmetry in myopia.

Dermatoglyphic alterations obtained in this study, manifested by the degree of variations in measured parameters-ridge counts and fluctuating asymmetry, identified myopic males as the group with the most pronounced differences. The variables that have been highlighted for their significant scores between myopic and control males were higher ridge counts on left and right ring and little finger. Consequently, this group also recorded significant increase in TRC. On the contrary, the only significant variation found in females stemmed from the lower FRC on the left little finger of myopic females in relation to control females. Since that morphogenesis of some dermatoglyphic features is associated to specific stages of prenatal development, it has been suggested that TRC may be considered as an index of early foetal growth rate [34], influenced by stimulating or inhibiting factors [20]. According to Meier et al. [30] males are late maturers and due to the later than average ridge formation, along with a delay in volar pad regression, are found to have larger and more complex dermatoglyphic patterns, such as whorls, and increased digital ridge counts.

Fluctuating asymmetry is a concept first described by Ludwig [27] as a sign of ontogenic stability. Ever since it is one of the most common used tools in measuring developmental stability, i.e. ability of an organism to moderate its development against genetic or environmental stresses. Increasing fluctuating asymmetry is in human populations linked to some indicators of developmental stability such as morbidity and number of offspring [43] or length of gestation [26], as well as to specific multifactorial disorders $[9,38]$.

Our analysis of fluctuating asymmetry between homologous fingers showed that myopic individuals of both sexes have higher degree of fluctuating asymmetry in comparison to controls, but the only significance refers to middle finger in myopic males along with significance of borderline level for thumb and ring finger. This might implicate somewhat greater developmental instability in myopic males, i.e. greater vulnerability to adverse environmental influences, and thus be in agreement with a hypothesis that males may be less canalised in their growth and development than females [41]. The earliest paper concerning environmental impact on males' development appear 
Table 1. Ridge count means and standard deviation (SD)

\begin{tabular}{|c|c|c|c|c|c|c|c|c|}
\hline & \multicolumn{4}{|c|}{ Males } & \multicolumn{4}{|c|}{ Females } \\
\hline & \multicolumn{2}{|c|}{ Control (n = 25) } & \multicolumn{2}{|c|}{ Myopia (n = 25) } & \multicolumn{2}{|c|}{ Control $(n=26)$} & \multicolumn{2}{|c|}{ Myopia (n = 26) } \\
\hline & Mean & SD & Mean & SD & Mean & SD & Mean & SD \\
\hline FRCL1 & 17,480 & 6,838 & 16,480 & 5,058 & 14,692 & 5,562 & 14,884 & 5,361 \\
\hline FRCL2 & 12,280 & 7,242 & 13,800 & 6,626 & 11,076 & 6,157 & 8,692 & 8,073 \\
\hline FRCL3 & 12,320 & 5,843 & 14,680 & 2,511 & 14,307 & 5,576 & 11,846 & 7,708 \\
\hline FRCL4 & 14,520 & 4,601 & 17,360 & 3,684 & 16,769 & 4,411 & 15,961 & 5,257 \\
\hline FRCL5 & 12,760 & 4,719 & 16,200 & 2,692 & 15,038 & 4,753 & 12,153 & 4,369 \\
\hline FRCR1 & 19,360 & 4,414 & 20,440 & 2,814 & 20,115 & 4,537 & 18,153 & 4,522 \\
\hline FRCR2 & 12,080 & 7,222 & 15,120 & 4,918 & 11,115 & 7,016 & 11,653 & 7,699 \\
\hline FRCR3 & 11,840 & 5,997 & 12,520 & 6,028 & 13,384 & 4,079 & 11,461 & 7,100 \\
\hline FRCR4 & 14,520 & 5,205 & 18,920 & 3,463 & 17,346 & 4,621 & 15,307 & 5,409 \\
\hline FRCR5 & 11,680 & 5,406 & 16,320 & 3,091 & 13,961 & 4,677 & 12,307 & 5,626 \\
\hline TRC & 139,160 & 45,697 & 160,800 & 20,194 & 147,423 & 36,001 & 132,423 & 45,007 \\
\hline
\end{tabular}

FRC — finger ridge counts; TRC — total ridge count; $L$ - left; $R$ - right

Table 2. Differences in mean ridge counts between examined groups (ANOVA)

\begin{tabular}{lccccc} 
& \multicolumn{2}{c}{ Males } & & & \multicolumn{2}{c}{ Females } \\
\cline { 2 - 3 } \cline { 5 - 6 } & $\mathbf{F}$ & $\mathbf{p}$ & $\mathbf{F}$ & $\mathbf{p}$ \\
\hline FRCL1 & 0.3455 & 0.559412 & & 0.0161 & 0.89951 \\
FRCL2 & 0.5993 & 0.442636 & & 1.4341 & 0.236748 \\
FRCL3 & 3.442 & 0.069706 & & 1.7404 & 0.193094 \\
FRCL4 & 5.8026 & 0.019889 & & 0.3601 & 0.551164 \\
FRCL5 & 10.0205 & 0.002688 & & 5.1889 & 0.02704 \\
FRCR1 & 1.0637 & 0.307538 & & 2.4375 & 0.124773 \\
FRCR2 & 3.0259 & 0.088353 & & 0.0695 & 0.793182 \\
FRCR3 & 0.1599 & 0.691066 & & 1.4337 & 0.2368 \\
FRCR4 & 12.3827 & 0.000959 & & 2.1344 & 0.15028 \\
FRCR5 & 13.8769 & 0.000514 & & 1.3283 & 0.254594 \\
TRC & 4.6903 & 0.035332 & & 1.7611 & 0.190516 \\
\hline
\end{tabular}

FRC — finger ridge counts; TRC — total ridge count; $L$ - left; $R$ - right

Table 3. Differences in fluctuating asymmetry correlation coefficients between examined groups

\begin{tabular}{|c|c|c|c|c|c|c|c|c|}
\hline \multirow[t]{3}{*}{ Fingers } & \multicolumn{4}{|c|}{ Males } & \multicolumn{4}{|c|}{ Females } \\
\hline & Control & Myopia & & & Control & Myopia & & \\
\hline & $1-r^{2}$ & $1-r^{2}$ & $z$ & $\mathbf{p}$ & $1-r^{2}$ & $1-r^{2}$ & $z$ & $\mathbf{p}$ \\
\hline Thumb & 0.443 & 0.792 & 1.568 & 0.058 & 0.387 & 0.612 & 1.094 & 0.137 \\
\hline Index & 0.429 & 0.552 & 0.584 & 0.28 & 0.430 & 0.758 & 1.514 & 0.065 \\
\hline Middle & 0.517 & 0.955 & 2.127 & 0.017 & 0.478 & 0.686 & 0.948 & 0.172 \\
\hline Ring & 0.365 & 0.707 & 1.608 & 0.054 & 0.414 & 0.674 & 1.222 & 0.111 \\
\hline Little & 0.312 & 0.581 & 1.38 & 0.084 & 0.556 & 0.632 & 0.344 & 0.365 \\
\hline
\end{tabular}


to be Greulich's et al. [14], who found that among children who survived the atomic bombing of Hiroshima and Nagasaki growth and maturation of males had been affected more adversely by environmental stress than that of females.

Asymmetry between the dermatoglyphic characteristics, as postulated by Naugler and Ludman [33], may signify relatively unstable genetic control during embryogenesis, identifying males as more subjected to influences of intrauterine environment $[4,19]$. One of the theories that might shed more light on the hypothesis that males are more sensitive to prenatal insults, which may be followed by atypical morphological traits and higher asymmetry, suggests the influence of prenatal circulating hormones, specifically prenatal testosterone. Prenatal testosterone might be related to slowed maturation, exposing dermatoglyphic morphogenesis longer to adverse influences. Possible mechanism by which testosterone modifies developmental rate might be through its stimulating effect on both epidermal and nerve growth factor [16-18].

Our results, although modest considering fluctuating asymmetry, might be suggestive to an underlying vulnerability that interacts with oculogenesis and environmental factors, contributing to the later onset of myopia in males. The limitation of this study is relatively small sample, which may cause missing of some differences due to the lack of statistical power.

\section{CONCLUSIONS}

Considering the overall findings of this study we may point to dermatoglyphics role as morphological biomarker, especially in myopic males, selecting them as the group with major alterations in finger ridge counts and fluctuating asymmetry score, which might be suggestive of delayed maturation and higher developmental instability. Although promising, the present results should be considered as preliminary until future investigations replicate them in a larger sample.

\section{REFERENCES}

1. Andreenko E, Baltova S. Sexual dimorphism in dermatoglyphic traits and fluctuating asymmetry in Bulgarians from northeast Bulgaria. Homo. 2017; 68(4): 316-327, doi: 10.1016/j.jchb.2017.05.006, indexed in Pubmed: 28867122.

2. Arrieta MI, Criado B, Hauspie R, et al. Effects of genetic and environmental factors on the $a-b, b-c$ and $c-d$ interdigital ridge counts. Hereditas. 1992; 117(2): 189-194, doi: 10.1111/j.1601-5223.1992.tb00173.x, indexed in Pubmed: 1459858.
3. Babler WJ. Embryologic development of epidermal ridges and their configurations. Birth Defects Orig Artic Ser. 1991; 27(2): 95-112, indexed in Pubmed: 1786361.

4. Bailey SM, Gershoff SN, McGandy RB, et al. A longitudinal study of growth and maturation in rural Thailand. Hum Biol. 1984; 56(3): 530-557, indexed in Pubmed: 6489996.

5. Boorman CJ, Shimeld SM. The evolution of left-right asymmetry in chordates. Bioessays. 2002; 24(11): 1004-1011, doi: 10.1002/bies.10171, indexed in Pubmed: 12386931.

6. Bots J, ten Broek CMA, Belien JAM, et al. Higher limb asymmetry in deceased human fetuses and infants with aneuploidy. Sci Rep. 2014; 4: 3703, doi: 10.1038/srep03703, indexed in Pubmed: 24424506.

7. Bouchard TJ, Lykken DT, McGue M, et al. Sources of human psychological differences: the Minnesota Study of Twins Reared Apart. Science. 1990; 250(4978): 223-228, doi: 10.1126/science.2218526, indexed in Pubmed: 2218526.

8. Cummins H, Midlo C. Fingerprints, palms and soles. Dover Publications Inc., New York. 1976.

9. de Bruin El, Graham JH, Louwerse A, et al. Mild dermatoglyphic deviations in adolescents with autism spectrum disorders and average intellectual abilities as compared to typically developing boys. Autism Res Treat. 2014; 2014: 968134, doi: 10.1155/2014/968134, indexed in Pubmed: 25478224.

10. Eid M, Gollwitzer M, Schmitt M. Statistik und Forschungsmethoden. Beltz Verlag, Weinheim, Basel. 2010.

11. Foster PJ, Jiang Y. Epidemiology of myopia. Eye (Lond). 2014; 28(2): 202-208, doi: 10.1038/eye.2013.280, indexed in Pubmed: 24406412.

12. Fuller IC. Dermatoglyphics: a diagnostic aid? J Med Genet. 1973; 10(2): 165-169, doi: 10.1136/jmg.10.2.165, indexed in Pubmed: 4714584.

13. Gangestad SW, Thornhill R. Individual differences in developmental precision and fluctuating asymmetry: a model and its implications. J Evol Biol. 2001; 12(2): 402-416, doi: 10.1046/j.1420-9101.1999.00039.x.

14. Greulich WW, Crimson CS, Turner ML. The physical growth and development of children who survived the atomic bombing of Hiroshima or Nagasaki. J Pediatr. 1953; 43(2): 121-145, doi: 10.1016/S0022-3476(53)80001-6, indexed in Pubmed: 13070125.

15. Heavner W, Pevny L. Eye development and retinogenesis. Cold Spring Harb Perspect Biol. 2012; 4(12), doi: 10.1101/ cshperspect.a008391, indexed in Pubmed: 23071378.

16. Jamison CS. Dermatoglyphics and the Geschwindhypothesis. I. Theoretical background and palmar results of dyslexia. In: Durham NM, Plato CC (eds). Trends in Dermatoglyphic Research. Studies in Human Biology. Springer, Dordrecht. 1990: 99-113.

17. Jamison CS, Jamison PL, Meier RJ. Effect of prenatal testosterone administration on palmar dermatoglyphic intercore ridge counts of rhesus monkeys (Macaca mulatta). Am J Phys Anthropol. 1994; 94(3): 409-419, doi: 10.1002/ ajpa.1330940309, indexed in Pubmed: 7943194.

18. Sorenson Jamison C, Meier RJ, Campbell BC. Dermatoglyphic asymmetry and testosterone levels in normal males. Am J Phys Anthropol. 1993; 90(2): 185-198, doi: 10.1002/ ajpa.1330900205, indexed in Pubmed: 8430752.

19. Jantz RL, Webb RS. Dermatoglyphic asymmetry as a measure of canalization. Ann Hum Biol. 1980; 7(5): 
489-493, doi: 10.1080/03014468000004611, indexed in Pubmed: 7235627.

20. Kahn HS, Ravindranath R, Valdez $R$, et al. Fingerprint ridgecount difference between adjacent fingertips (dR45) predicts upper-body tissue distribution: evidence for early gestational programming. Am J Epidemiol. 2001; 153(4): 338-344, doi: 10.1093/aje/153.4.338, indexed in Pubmed: 11207151.

21. Kücken M, Newell AC. Fingerprint formation. J Theor Biol. 2005; 235(1): 71-83, doi: 10.1016/j.jtbi.2004.12.020, indexed in Pubmed: 15833314.

22. Langsley N, Miller P, Byrne M, et al. Dermatoglyphics and schizophrenia: findings from the Edinburgh high risk study. Schizophr Res. 2005; 74(1): 122-124, doi: 10.1016/j. schres.2004.02.006, indexed in Pubmed: 15694762.

23. Leamy L. Genetic analysis of fluctuating asymmetry for skeletal characters in mice. J Hered. 1997; 88(2): 85-92, doi: 10.1093/oxfordjournals.jhered.a023082.

24. Lenhard W, Lenhard A. Hypothesis tests for comparing correlations. Psychometrica. 2014, doi: 10.13140/RG.2.1.2954.1367.

25. Li J, Zhang Q. Insight into the molecular genetics of myopia. Mol Vis. 2017; 23: 1048-1080, indexed in Pubmed: 29386878

26. Livshits G, Davidi L, Kobyliansky E, et al. Decreased developmental stability as assessed by fluctuating asymmetry of morphometric traits in preterm infants. Am J Med Genet. 1988; 29(4): 793-805, doi: 10.1002/ajmg.1320290409, indexed in Pubmed: 3400724.

27. Ludwig W. Rechts-Links-Problem im Tierreich und Beim Menschen. Springer-Verlag, Berlin Heidelberg. 1932.

28. Martín B, Fañanás L, Gutiérrez B, et al. Dermatoglyphic profile in 22q deletion syndrome. Am J Med Genet B Neuropsychiatr Genet. 2004; 128B(1): 46-49, doi: 10.1002/ ajmg.b.30034, indexed in Pubmed: 15211630.

29. Medland SE, Loesch DZ, Mdzewski B, et al. Linkage analysis of a model quantitative trait in humans: finger ridge count shows significant multivariate linkage to $5 q 14.1$. PLoS Genet. 2007; 3(9): 1736-1744, doi: 10.1371/journal. pgen.0030165, indexed in Pubmed: 17907812.

30. Meier RJ, Goodson CS, Roche EM. Dermatoglyphic development and timing of maturation. Hum Biol. 1987; 59(2): 357-373, indexed in Pubmed: 3596574.

31. Midlo C, Cummins H. Palmar and plantar dermatoglyphics in primates. Wistar Institute of Anatomy and Biology, Philadelphia. 1942.

32. Moler AP, Swaddle JP. Asymmetry, developmental stability and evolution. Oxford University Press, UK. 1997.
33. Naugler CT, Ludman MD. A case-control study of fluctuating dermatoglyphic asymmetry as a risk marker for developmental delay. Am J Med Genet. 1996; 66(1): 11-14, doi: 10.1002/(SICI)1096-8628(19961202)66:1<11::AIDAJMG3 > 3.0.CO;2-Z, indexed in Pubmed: 8957503.

34. Netley C, Rovet J. Relationships among brain organization, maturation rate, and the development of verbal and nonverbal ability. Language Functions and Brain Organization. Academic Press. 1983: 245-266, doi: 10.1016/b978-0-12635640-3.50019-9.

35. Nodari RJ, Sartoori G, Gin G, et al. Dermatoglyphic characteristics of hypertensives. Acta Medica Mediterr. 2016; 32(4): 1015, doi: 0.19193/0393-6384_2016_4_125.

36. Palmer AR, Strobeck C. Fluctuating Asymmetry: Measurement, Analysis, Patterns. Ann Rev Ecol Syst. 1986; 17(1): 391-421, doi: 10.1146/annurev.es.17.110186.002135.

37. Palmer A, Strobeck C, Chippindale A. Bilateral variation and the evolutionary origin of macroscopic asymmetries. Genetica. 1993; 89(1-3): 201-218, doi: 10.1007/bf02424514.

38. Russak OD, Ives $L$, Mittal VA, et al. Fluctuating dermatoglyphic asymmetries in youth at ultrahigh-risk for psychotic disorders. Schizophr Res. 2016; 170(2-3): 301-303, doi: 10.1016/j.schres.2015.12.013, indexed in Pubmed: 26723845.

39. Sinn R, Wittbrodt J. An eye on eye development. Mech Dev. 2013; 130(6-8): 347-358, doi: 10.1016/j. mod.2013.05.001, indexed in Pubmed: 23684892.

40. Sokal R. Rohlf F. Biometry. 4th ed. W.H. Freeman, New York. 2011.

41. Stini WA. Reduced sexual dimorphism in upper arm muscle circumference associated with protein-deficient diet in a South American population. Am J Phys Anthropol. 1972; 36(3): 341-351, doi: 10.1002/ajpa.1330360304, indexed in Pubmed: 5035060.

42. Van Dongen S, Ten Broek C, Bots J, et al. Changes of Fluctuating Asymmetry with Age in Human Fetuses and Young Infants. Symmetry. 2017; 9(3): 44, doi: 10.3390/ sym9030044.

43. Waynforth D. Fluctuating asymmetry and human male lifehistory traits in rural Belize. Proc Biol Sci. 1998; 265(1405): 1497-1501, doi: 10.1098/rspb.1998.0463, indexed in Pubmed: 9744105.

44. Young TL, Metlapally R, Shay AE. Complex trait genetics of refractive error. Arch Ophthalmol. 2007; 125(1): 38-48, doi: 10.1001/archopht.125.1.38, indexed in Pubmed: 17210850. 